\title{
Pengaruh Plant Growth Promoting Rhizobacteria Terhadap Bibit dan Pertumbuhan Awal Pepaya
}

\author{
Effect of Plant Growth Promoting Rhizobacteria to Papaya Seedling and Early Growth at Field
}

\author{
Samson Bin Nasib, Ketty Suketi ${ }^{*}$, dan Winarso Drajad Widodo
}

Departemen Agronomi dan Hortikultura, Fakultas Pertanian, Institut Pertanian Bogor

(Bogor Agricultural University), Jalan Meranti, Kampus IPB Darmaga, Bogor 16680, Indonesia

Telp.\& Faks. 62-251-8629353 e-mail agronipb @indo.net.id

*Penulis untuk korespondensi: kettysuketi@yahoo.com

Disetujui 18 Januari 2016/ Published online 25 Januari 2016

\begin{abstract}
This study aims to determine the effect of PGPR on seed and early growth stage of papaya. Experiments were carried out from February to May 2015 in the Experimental field of Center for Tropical Horticultural Studies IPB Pasir Kuda Ciomas, Bogor. By using 2 factors and 5 repeatation of planned groups. PGPR concentration that used as a treatment are $\left(5 \mathrm{ml} \mathrm{L}{ }^{-1}, 10 \mathrm{ml} L^{-1}\right.$ and $\left.15 \mathrm{ml} \mathrm{L} \mathrm{L}^{-1}\right)$ and soaking time of PGPR are (30 minutes, 60 minutes, 90 minutes and 120 minutes). Data were analyzed by $F$ test and treatment effect was analyzed by DMRT (Duncan Multiple Range Test) at the level of 5\% confidence interval. The research results in polybag showed that the concentration, soaking time and interaction between concentration has effect on number of leaves produced and stem diameter at the nursery phase. The results of research in the field shows that the concentration of PGPR solution, soaking time and interaction between concentration of PGPR solution with soaking time did not shown any affect on plant height, leaf number, petiole length, leaf width, leaf length, when the first flowers appear, height position of flowers, the number of female tree, the number of hermaphrodite trees, the number of female flowers and the number of hermaphrodite flowers. PGPR concentration has significant effect on the length of petiole 5 weeks after planted.
\end{abstract}

Keywords: concentration of solution, PGPR, soaking time

\begin{abstract}
ABSTRAK
Penelitian ini bertujuan untuk mengetahui pengaruh PGPR pada bibit dan pertumbuhan awal pepaya. Percobaan dilakukan dari bulan Februari sampai Mei 2015 di Kebun Percobaan Pusat Kajian Hortikultura Tropika IPB Pasirkuda Ciomas, Bogor, dengan rancangan kelompok lengkap teracak 2 faktor dan 5 ulangan. Perlakuan adalah konsentrasi larutan PGPR $\left(5 \mathrm{ml} \mathrm{L}\right.$, $10 \mathrm{ml} \mathrm{L}^{-1}$ dan $\left.15 \mathrm{ml} \mathrm{L} \mathrm{L}^{-1}\right)$ dan lama perendaman PGPR (30 menit, 60 menit,90 menit dan 120 menit). Data yang diperoleh dianalisis dengan uji $F$ dan perlakuan berpengaruh dianalisis dengan DMRT (Duncan Multiple Range Test) pada taraf selang kepercayaan 5\%. Hasil penelitian di polybag menunjukkan bahwa konsentrasi larutan PGPR, lama perendaman PGPR dan interaksi antara konsentrasi PGPR dengan lama perendaman PGPR mempengaruhi jumlah daun dan diameter batang di fase pembibitan. Hasil penelitian di lapangan menunjukkan bahwa konsentrasi larutan PGPR, lama perendaman PGPR dan interaksi antara konsentrasi PGPR dengan lama perendaman PGPR tidak mempengaruhi tinggi tanaman, jumlah daun, panjang petiol, lebar daun, panjang daun, waktu bunga pertama muncul, tinggi kedudukkan bunga, jumlah pohon betina, jumlah pohon hermaprodit, jumlah bunga betina dan jumlah bunga hermaprodit. Konsentrasi PGPR mempengaruhi panjang petiol pada 5 minggu setelah tanam.
\end{abstract}

Kata kunci : konsentrasi larutan, lama perendaman, PGPR 


\section{PENDAHULUAN}

Tanaman pepaya (Carica papaya L.) merupakan salah satu komoditas buah tropika utama yang sangat populer di Indonesia karena relatif mudah untuk dibudidayakan dan banyak manfaatnya. Buah pepaya tidak hanya dijadikan bahan konsumsi sebagai buah segar tetapi juga sebagai bahan industri contohnya pembuatan saos, manisan, asinan, bahan baku rujak dan berbagai jenis makanan lain.

Kebutuhan pepaya bagi masyarakat Indonesia tidak hanya dipenuhi dari produksi domestik tetapi juga dari impor. Perkembangan volume impor pepaya selama periode tahun 2007-2011 mengalami peningkatan rata-rata sebesar 79\%/tahun (PKP, 2013). Adanya impor buah pepaya menunjukkan bahwa peningkatan permintaan masyarakat Indonesia terhadap buah pepaya belum diimbangi dengan peningkatan suplai buah pepaya yang sesuai permintaan konsumen seperti kuantitas, kualitas dan kontinuitas. Rata-rata konsumsi buah-buahan di Indonesia pada tahun 2005-2011 mencapai 28.71 $\mathrm{kg} / \mathrm{kapita} / \mathrm{tahun}$ dengan kisaran 23.56-31.93 kg/kapita/tahun (PKHT, 2013).

Produktivitas pepaya perlu terus ditingkatkan. Salah satu upaya yang dapat dilakukan dengan pembibitan yang baik dan efektif, karena bibit merupakan tahap awal yang sangat menentukan dalam keberhasilan penanaman dan produksi di kemudian hari. Faktor yang menyebabkan rendahnya produksi adalah tidak optimalnya pertumbuhan bibit pepaya, kondisi curah hujan yang tidak merata sepanjang tahun, serta adanya hama dan penyakit. Tidak optimalnya pertumbuhan bibit tanaman pepaya disebabkan petani sering menggunakan media tanam yang tingkat kesuburannya relatif rendah, dan menggunakan media tanam yang tidak sesuai sehingga mendatangkan penyakit pada pembibitan.

Menurut penelitian Utami et al. (2013), terdapat dua jenis komposisi media tanam yang dapat mempengaruhi tinggi tanaman, jumlah daun, diameter batang, bobot bibit per polybag dan waktu bunga pertama muncul di lapangan. Komposisi media tanam yang pertama dengan menggunakan tanah, pupuk kandang ayam dan sekam dengan perbandingan volume 1:1:1. Komposisi jenis media tanam yang kedua dengan mengunakan tanah, pupuk kandang ayam dan cocopeat dengan perbandingan volume 1:1:1. Kedua jenis media tanam ini memiliki bobot ringan serta dapat mendukung pertumbuhan bibit pepaya di lapangan.
Cara lain untuk meningkatkan pertumbuhan bibit pepaya selain media tanam adalah dengan menggunakan PGPR (plant growth promoting rhizobacteria) atau rhizobakteri. PGPR adalah sejenis bakteri yang hidup di sekitar perakaran tanaman, hidupnya secara berkoloni menyelimuti akar tanaman pada lapisan tanah tipis antara 1 hingga $2 \mathrm{~mm}$ di sekitar zona perakaran. Hasil penelitian yang dilakukan oleh Maunuksela (2004) didapatkan bahwa rhizobakteria kelompok Bacillus spp, Pseudomonas fluorescens dan Serratia spp, memiliki kemampuan memproduksi hormon tumbuh seperti asam indol asetat (IAA) yang dapat memacu pertumbuhan tanaman. Penggunaan PGPR dalam pembibitan tanaman telah dilakukan oleh Taufik (2010) pada tanaman cabai. Hasil penelitian menunjukkan penggunaan PGPR pada benih cabai mampu meningkatkan pertumbuhan vegetatif dan generatif tanaman cabai.

Oleh sebab itu, penelitian ini menggunakan kombinasi PGPR dengan media tanam diharapkan dapat menjadi alternatif untuk menghasilkan bibit dan pertumbuhan awal pepaya yang baik sehingga diharapkan dapat meningkatkan produktivitas pepaya.

\section{BAHAN DAN METODE}

Penelitian dilaksanakan pada bulan Februari hingga Mei 2015 di Kebun Percobaan Pusat Kajian Hortikultura Tropika Pasirkuda Ciomas, Bogor. Pemeliharaan bibit dilakukan di screen house selama 4 minggu. Penanaman bibit di lapangan dilakukan pada luasan $1875 \mathrm{~m}^{2}$. Dalam penelitian Utami et al. (2013) kebutuhan luas lahan yang dibutuhkan seluas $1500 \mathrm{~m}^{2}$. Bahan yang digunakan dalam penelitian ini adalah benih pepaya kultivar Sukma (IPB-6C), PGPR WISH (RhizomaX) dan pupuk kandang kambing. Media tanam yang digunakan yaitu tanah, pupuk kandang kambing, dan arang sekam. Alat yang digunakan dalam penilitian ini adalah polybag ukuran $10 \mathrm{~cm} \times 15 \mathrm{~cm}$, timbangan, wadah, alatalat pertanian, color chart, meteran, penggaris, jangka sorong digital, label, dan alat tulis.

Percobaan ini menggunakan rancangan faktorial dengan dua faktor disusun menggunakan Rancangan Kelompok Lengkap Teracak (RKLT). Faktor pertama adalah konsentrasi larutan PGPR yang digunakan yaitu $15 \mathrm{ml} \mathrm{L}^{-1}$ air (K1), $10 \mathrm{ml} \mathrm{L}^{-1}$ air (K2), dan $5 \mathrm{ml} \mathrm{L}^{-1}$ air (K3). Faktor kedua adalah lama perendaman yaitu 30 menit (P1), 60 menit (P2), 90 menit (P3) dan 120 menit (P4). Jika hasil sidik ragam berpengaruh nyata terhadap uji-F maka akan dilakukan uji lanjut DMRT 
(Duncan Multiple Range Test) pada taraf selang kepercayaan 5\%. Percobaan terdiri atas 12 kombinasi dengan 5 ulangan sehingga terdapat 60 satuan percobaan. Setiap satuan percobaan terdiri atas 4 bibit pepaya sehingga jumlah tanaman yang digunakan 240 tanaman. Pengamatan dilakukan pada 3 contoh bibit sehingga jumlah yang diamati sebanyak 180 tanaman.

Media tanam yang digunakan dicampur sesuai dengan perbandingan 1:1:1 yaitu tanah, pupuk kandang kambing dan arang sekam, dimasukkan ke dalam polybag berukuran $10 \mathrm{~cm} \mathrm{x}$ $15 \mathrm{~cm}$ dan diletakkan di dalam screen house. Sebelum benih ditanam ke polybag, benih dicuci dulu hingga bersih (3-4 kali). Kemudian benih direndam dalam larutan PGPR dengan konsentrasi dan lama perendaman dengan yang ditentukan. Benih dikeringkan di tempat yang teduh sebelum ditanam. Benih yang ditanam sebanyak 8 benih setiap kombinasi perlakuan, sehingga jumlah benih yang digunakan sebanyak 480 butir. Penanaman di polybag dengan kedalaman lubang tanam 1-2 cm. Penyiraman PGPR sebanyak 200 $\mathrm{ml} / 141$ air dilakukan 1 minggu sebelum dipindah tanamkan ke lahan.

Selama 1 bulan untuk menyeragamkan bibit pepaya, dilakukan pemeliharan bibit seperti penyiraman, pengendalian gulma, serta pengendalian hama dan penyakit. Lahan penanaman dibersihkan, penanaman dalam bentuk sistem piringan dengan jarak tanam $2.5 \mathrm{~m}$ x $2.5 \mathrm{~m}$ dengan ukuran lubang tanam $50 \mathrm{~cm}$ x $50 \mathrm{~cm}$ x 40 $\mathrm{cm}$. Pemberian pupuk organik dilakukan 2 minggu sebelum tanam. Lubang tanam dibiarkan terbuka dan terpapar sinar matahari selama 2 minggu.

Pemindahan bibit dilakukan setelah bibit berumur 4 minggu setelah tanam. Pemindahan bibit dilakukan dengan mengangkut bibit berserta media tanamnya dengan kriteria bibit yang sehat dan baik yaitu memiliki tinggi tanaman sekitar 9$11 \mathrm{~cm}$ (Suketi dan Imanda, 2011). Bibit yang dipindahkan ke lapangan sebanyak 240 bibit pepaya.

Pemeliharaan yang dilakukan meliputi
pengairan, pemupukan, sanitasi, serta pengendalian hama dan penyakit. Pengairan dilakukan pada pagi dan sore hari untuk mengurangi penguapan di siang hari. Pemupukan dilakukan pada awal penanaman di lapangan menggunakan pupuk kandang kambing dengan dosis $15 \mathrm{~kg} /$ tanaman dan dilakukan 2 minggu sebelum penanaman bibit. Pemupukan susulan dilakukan setelah bibit pepaya berumur 4 bulan menggunakan pupuk kandang kambing dengan dosis 20-30 kg/tanaman (Suketi dan Imanda, 2011). Sanitasi yang dilakukan berupa pembumbunan, penyiangan gulma, dan membuang bagian tanaman yang terserang penyakit. Lakukan penyiraman PGPR sebanyak $200 \mathrm{ml}$ per $14 \mathrm{~L}$ air 1 bulan sekali hingga berbunga pertama.

Pengamatan yang dilakukan terdiri atas pengamatan perkecambahan benih pepaya di polybag yaitu waktu muncul kecambah (Hari Setelah Tanam/HST) dan daya berkecambah \% (30 HST). Pengamatan bibit pepaya di polybag yaitu bobot bibit setiap perlakuan per polybag $(\mathrm{g})$, bobot bibit akhir per polybag (g) dilakukan pada saat bibit 10 hari dipindahkan ke lapangan, tinggi tanaman $(\mathrm{cm})$ diukur dari atas permukaan media hingga titik tumbuh (4 Minggu Setelah Tanam /MST), jumlah daun, semua daun yang telah membuka sempurna (helai) (4 MST) dan diameter batang $(\mathrm{mm})$ pada ketinggian $5 \mathrm{~cm}$ dari atas permukaan media tanam (4 MST) dan pengamatan tanaman di lapangan yaitu tinggi tanaman, diukur dari atas permukaan tanah sampai titik tumbuh $(\mathrm{cm})$ (5-11 MST), jumlah daun, semua daun yang telah membuka sempurna (helai) (5-11 MST), diameter batang, diukur pada ketinggian $5 \mathrm{~cm}$ dari permukaan tanah $(\mathrm{mm})$ (11MST) menggunakan jangka sorong digital, panjang petiol $(\mathrm{cm})$ diukur dari pangkal hingga ujung tangkai daun (5-11 MST), warna petiol diukur dengan menggunakan Color Chart (Exclusively for Training Program of Variety Protection Center), petiol yang diukur adalah petiol dari daun kesepuluh yang dihitung dari ujung batang, panjang daun $(\mathrm{cm})$ diukur pada jari tengah tulang daun. Daun yang diukur adalah tiga daun tertua (5-11MST), lebar daun $(\mathrm{cm})$ diukur pada bagian daun terlebar (5-11 MST), Waktu berbunga pertama, jumlah pohon betina dan hermaprodit, jumlah bunga betina dan bunga hermaprodit perpohon, dan tinggi kedudukan bunga pertama hermaprodit dan betina $(\mathrm{cm})$ diukur dari permukaan tanah, awal pengukuran ditandai spidol agar pengukuran awal tetap dari permukaan tanah.

\section{HASIL DAN PEMBAHASAN}

\section{Warna Petiol pada Fase Vegetatif}

Karakter kualitatif yang diamati pada penelitian ini adalah warna petiol. Penentuan warna petiol diambil dari daun kesepuluh yang dihitung dari ujung batang agar lebih mudah dan seragam karena dalam satu tanaman warna petiolnya tidak sama tergantung kematangan daun. Semakin matang daun maka warna petiol akan semakin merah keunguan. Hasil penelitian menunjukkan bahwa konsentrasi larutan dan lama 
perendaman PGPR tidak mempengaruhi warna petiol. Menurut Color Chart (Exclusively for Training Program of Variety Protection Center) warna petiol pada semua perlakuan sama yaitu kode 99CC33 berwarna hijau muda. Hal ini diduga disebabkan oleh pengaruh gen yang mempengaruhi setiap karakter pada tanaman pepaya. Menurut penelitian Suketi et al. (2011) warna petiol itu dikendalikan oleh gen yang mempunyai pengaruh yang sangat besar terhadap penampilan, sehingga pengaruh lingkungan terhadap karakter tersebut kecil.

\section{Pertumbuhan Bibit Pepaya di Polybag}

Penyemaian benih pepaya tidak disemai dengan menggunakan tray tetapi langsung dilakukan di polybag dengan menggunakan campuran media tanam tanah, pupuk kandang kambing, dan arang sekam dengan perbandingan $1: 1: 1$. Hal tersebut dilakukan untuk menghindari kerusakan akar pada saat bibit pepaya dipindahtanamkan dan mempersingkat waktu tanam di lapangan.

Hasil analisis ragam menunjukkan bahwa perlakuan konsentrasi PGPR, lama perendaman PGPR dan interaksinya pada benih pepaya di polybag tidak mempengaruhi waktu muncul kecambah, tinggi tanaman dan bobot bibit per polybag pada 4 MST, tetapi mempengaruhi jumlah daun dan diameter batang pada 4 MST (Tabel 1).

Daya berkecambah benih adalah tolok ukur bagi kemampuan benih untuk tumbuh normal dan berproduksi normal pada kondisi lingkungan optimum. Daya berkecambah benih pepaya Sukma (IPB-6C) setiap perlakuan tidak ada perbedaan yang signifikan antara perlakuan. Daya berkecambah benih pepaya setiap perlakuan mencapai $100 \%, 97 \%$ dan $93 \%$.

Analisis uji lanjut pertumbuhan bibit pepaya di polybag pada perlakuan konsentrasi PGPR 4 MST (Tabel 2) menyimpulkan bahwa perlakuan konsentrasi K2 menghasilkan jumlah daun paling sedikit dan berbeda dibandingkan dengan perlakuan $\mathrm{K} 3$ dan berbeda dengan perlakuan pembanding K1. Analisis uji lanjut perlakuan konsentrasi diameter batang pada 4 MST (Tabel 2) dapat disimpulkan bahwa perlakuan pembanding K1 menghasilkan diameter batang terkecil dan berbeda dibandingkan dengan perlakuan konsentrasi K2 dan K3.

Tabel 1. Hasil analisis ragam pengaruh perlakuan PGPR terhadap pertumbuhan bibit pepaya di polybag

\begin{tabular}{|c|c|c|c|c|}
\hline Peubah & Konsentrasi & Perendaman & $\begin{array}{c}\text { Konsentrasi* } \\
\text { perendaman }\end{array}$ & $\mathrm{KK}(\%)$ \\
\hline Tinggi tanaman & $0.14^{\mathrm{tn}}$ & $1.39^{\mathrm{tn}}$ & $0.03^{\text {tn }}$ & 5.50 \\
\hline Jumlah daun & $4.20^{* *}$ & $0.62^{\mathrm{tn}}$ & $0.44^{\mathrm{tn}}$ & 8.05 \\
\hline Diameter batang & $0.18^{* *}$ & $0.18^{* *}$ & $1.58^{* *}$ & 6.74 \\
\hline Waktu muncul kecambah & $0.02^{\mathrm{tn}}$ & $0.23^{\mathrm{tn}}$ & $0.07^{\mathrm{tn}}$ & 2.86 \\
\hline Bobot bibit per polybag & $248.98^{\text {tn }}$ & $304.58^{\text {tn }}$ & $563.04^{\mathrm{tn}}$ & 47.72 \\
\hline
\end{tabular}

Tabel 2. Pertumbuhan bibit pepaya pada perlakuan konsentrasi PGPR 4 MST

\begin{tabular}{lccccc}
\hline Peubah & $\begin{array}{c}\text { Waktu } \\
\text { muncul kecambah }\end{array}$ & $\begin{array}{c}\text { Tinggi } \\
\text { tanaman }(\mathrm{cm})\end{array}$ & $\begin{array}{c}\text { Jumlah } \\
\text { daun (helai) }\end{array}$ & $\begin{array}{c}\text { Diameter } \\
\text { batang }(\mathrm{mm})\end{array}$ & $\begin{array}{c}\text { Bobot bibit } \\
\text { per polybag }(\mathrm{g})\end{array}$ \\
\hline K1 & 10.55 & 8.99 & $3.96^{\mathrm{a}}$ & $1.90^{\mathrm{b}}$ & 34.68 \\
K2 & 10.61 & 9.07 & $3.34^{\mathrm{b}}$ & $1.99^{\mathrm{a}}$ & 32.87 \\
K3 & 10.61 & 9.11 & $3.80^{\mathrm{a}}$ & $2.03^{\mathrm{a}}$ & 39.68 \\
\hline
\end{tabular}

Keterangan : Angka yang diikuti huruf yang sama pada kolom yang sama tidak berbeda nyata pada uji Duncan taraf $5 \%, \mathrm{~K} 1=15 \mathrm{ml}$ $\mathrm{L}^{-1}$ air, $\mathrm{K} 1=15 \mathrm{ml} \mathrm{L}^{-1}$ air, $\mathrm{K} 2=10 \mathrm{ml} \mathrm{L}^{-1}$ air, $\mathrm{K} 3=5 \mathrm{ml} \mathrm{L}^{-1}$ air

Tabel 3. Pertumbuhan bibit pepaya pada perlakuan perendaman PGPR 4 MST

\begin{tabular}{lccccc}
\hline Peubah & $\begin{array}{c}\text { Waktu } \\
\text { muncul kecambah }\end{array}$ & $\begin{array}{c}\text { Tinggi } \\
\text { tanaman }(\mathrm{cm})\end{array}$ & $\begin{array}{c}\text { Jumlah } \\
\text { daun (helai) }\end{array}$ & $\begin{array}{c}\text { Diameter } \\
\text { batang }(\mathrm{mm})\end{array}$ & $\begin{array}{c}\text { Bobot } \\
\text { bibit per polybag (g) }\end{array}$ \\
\hline P1 & 10.48 & 8.92 & 3.66 & $1.98^{\mathrm{b}}$ & 40.83 \\
P2 & 10.48 & 9.3 & 3.55 & $2.13^{\mathrm{a}}$ & 30.83 \\
P3 & 10.68 & 8.94 & 3.81 & $1.91^{\mathrm{bc}}$ & 33.33 \\
P4 & 10.71 & 9.07 & 3.76 & $1.87^{\mathrm{c}}$ & 38.00 \\
\hline K
\end{tabular}

Keterangan : Angka yang diikuti huruf yang sama pada kolom yang sama tidak berbeda nyata pada uji Duncan taraf $5 \%$, P1 $=30$ menit, $\mathrm{P} 2=60$ menit, $\mathrm{P} 3=90$ menit, $\mathrm{P} 4=120$ menit 
Analisis uji lanjut pertumbuhan bibit pepaya di polybag pada perlakuan perendaman PGPR 4 MST (Tabel 3) menyimpulkan bahwa perlakuan perendaman P2 menghasilkan diameter batang paling besar dan berbeda dibandingkan dengan perlakuan P3, P4 dan perlakuan pembanding P1.

Analisis uji lanjut pertumbuhan bibit pepaya di polybag 4 MST (Tabel 4) menyimpulkan bahwa perlakuan K1P4, K2P4 dan K3P4 menghasilkan diameter batang terkecil dan berbeda dibandingkan dengan perlakuan K1P2, $\mathrm{K} 2 \mathrm{P} 1, \mathrm{~K} 2 \mathrm{P} 2$, K3P1, K3P2 serta berbeda dengan perlakuan pembanding K1P1. Konsentrasi dan lama perendaman PGPR pada benih pepaya memberi respon yang positif dengan diameter batang dan jumlah daun di polybag. Hal ini diduga karena adanya interaksi antara konsentrasi larutan dan lama perendaman PGPR pada benih pepaya. Harjadi (2009) menyatakan bahwa meningkatnya pertumbuhan diameter batang dan jumlah daun akan meningkatkan penyerapan unsur hara dan air yang diserap oleh akar tanaman, sehingga proses fotosintesis akan lebih efektif.

Pertumbuhan bibit di polybag yang diukur berdasarkan variabel bobot bibit per polybag tidak menunjukkan perbedaan antara perlakuan. Hal ini terjadi disebabkan media tanam dan bibit pepaya yang digunakan setiap perlakuan sama sehingga memiliki bobot yang sama. Menurut hasil penelitian Suketi dan Imanda (2011) komposisi campuran media tanam tanah, pupuk kandang, dan arang sekam dengan perbandingan 2:1:1 merupakan media paling baik untuk bibit pepaya serta memiliki bobot bibit per polybag yang paling ringan dan dapat mendukung pertumbuhan bibit pepaya di lapangan.

Tabel 4. Pertumbuhan bibit pepaya di polybag dan bobot bibit pepaya 4 MST

\begin{tabular}{lccccc}
\hline Peubah & $\begin{array}{c}\text { Waktu muncul } \\
\text { Kecambah }\end{array}$ & $\begin{array}{c}\text { Tinggi } \\
\text { Tanaman }(\mathrm{cm})\end{array}$ & $\begin{array}{c}\text { Jumlah } \\
\text { daun (helai) }\end{array}$ & $\begin{array}{c}\text { Diameter batang } \\
(\mathrm{mm})\end{array}$ & $\begin{array}{c}\text { Bobot bibit per } \\
\text { polybag }(\mathrm{g})\end{array}$ \\
\hline K1P1 & 10.45 & 8.97 & 3.80 & $2.01^{\mathrm{b}}$ & 30.00 \\
K1P2 & 10.40 & 9.65 & 3.85 & $2.24^{\mathrm{a}}$ & 30.00 \\
K1P3 & 10.75 & 8.59 & 4.10 & $1.89^{\mathrm{bc}}$ & 32.50 \\
K1P4 & 10.60 & 8.76 & 4.10 & $1.67^{\mathrm{c}}$ & 46.25 \\
K2P1 & 10.60 & 8.88 & 3.50 & $2.03^{\mathrm{b}}$ & 32.50 \\
K2P2 & 10.60 & 9.23 & 3.15 & $2.21^{\mathrm{a}}$ & 37.50 \\
K2P3 & 10.55 & 9.29 & 3.35 & $1.98^{\mathrm{bc}}$ & 31.25 \\
K2P4 & 10.70 & 8.90 & 3.35 & $1.71^{\mathrm{c}}$ & 30.25 \\
K3P1 & 10.40 & 8.92 & 3.70 & $2.01^{\mathrm{b}}$ & 60.00 \\
K3P2 & 10.45 & 9.04 & 3.65 & $2.18^{\mathrm{a}}$ & 25.00 \\
K3P3 & 10.75 & 8.95 & 4.00 & $1.87^{\mathrm{bc}}$ & 36.25 \\
K3P4 & 10.85 & 9.55 & 3.85 & $1.62^{\mathrm{c}}$ & 37.50 \\
\hline
\end{tabular}

Keterangan : Angka yang diikuti huruf yang sama pada kolom yang sama tidak berbeda nyata pada uji Duncan taraf 5\%, K1P1 = 15 $\mathrm{ml} \mathrm{L}-1$ air 30 menit, K1P2 $=15 \mathrm{ml} \mathrm{L}^{-1}$ air 60 menit, K1P3 $=15 \mathrm{ml} \mathrm{L}^{-1}$ air 90 menit, K1P4 $=15 \mathrm{ml} \mathrm{L}^{-1}$ air 120 menit, $\mathrm{K} 2 \mathrm{P} 1=10 \mathrm{ml} \mathrm{L}^{-1}$ air 30 menit, $\mathrm{K} 2 \mathrm{P} 2=10 \mathrm{ml} \mathrm{L}^{-1}$ air 60 menit, $\mathrm{K} 2 \mathrm{P} 3=10 \mathrm{ml} \mathrm{L}^{-1}$ air 90 menit, $\mathrm{K} 2 \mathrm{P} 4=10 \mathrm{ml} \mathrm{L}^{-1}$ air 120 menit, $\mathrm{K} 3 \mathrm{P} 1=5 \mathrm{ml} \mathrm{L}^{-1}$ air 30 menit, K3P2 $=5 \mathrm{ml} \mathrm{L}^{-1}$ air 60 menit, K3P3 $=5 \mathrm{ml} \mathrm{L}^{-1}$ air +90 menit, K3P4 = $5 \mathrm{ml}$ $\mathrm{L}^{-1}$ air 120 menit

\section{Pertumbuhan Awal Pepaya di Lapangan}

Bibit pepaya dipindahkan ke lapangan setelah berumur 4 MST di polybag, kemudian dilakukan pengamatan sampai 11 MST untuk mengetahui adaptasi pertumbuhannya di lapangan. Menurut Sujiprihati dan Suketi (2009) tujuan dari pembibitan adalah untuk mendapatkan bibit pepaya yang sehat, tumbuh optimal dan mempunyai adaptasi yang baik saat dipindahkan ke lapangan. Pertumbuhan tanaman di lapangan sangat dipengaruhi oleh faktor lingkungan seperti cuaca, curah hujan, hama dan penyakit. Menurut Gardner et al. (2008) faktor-faktor yang mempengaruhi pertumbuhan tanaman di lapangan dapat dikategorikan sebagai faktor eksternal (lingkungan) dan internal (genetik).
Berdasarkan hasil analisis ragam perlakuan konsentrasi, lama perendaman PGPR dan interaksinya tidak mempengaruhi tinggi tanaman, jumlah daun, panjang petiol, lebar daun, panjang daun dan diameter batang di lapangan kecuali panjang petiol pada 5 MST (Tabel 5). Hal ini disebabkan tidak adanya interaksi antara konsentrasi dan lama perendaman PGPR. Hal ini sesuai dengan hasil penelitian Dita (2014) yang menyatakan bahwa interaksi antara konsentrasi PGPR dengan lama perendaman PGPR pada tanaman seledri tidak berpengaruh nyata terhadap tinggi tanaman, jumlah daun, jumlah cabang, diameter batang, panjang akar, berat akar, jumlah akar dan intensitas serangan hama serta penyakit.

Hasil analisis uji lanjut perlakuan konsentrasi larutan yang memiliki panjang petiol terpanjang adalah $\mathrm{K} 1$ yaitu $3.32 \mathrm{~cm}$ (Tabel 5) 
dengan nilai konsentrasi PGPR tertinggi sebanyak $15 \mathrm{ml}$, sedangkan konsentrasi K2 dan K3 pada 5 MST menunjukkan panjang petiol yang rendah dan tidak berbeda nyata dengan nilai 3.01 dan $3.02 \mathrm{~cm}$. Panjang petiol yang rendah ini disebabkan oleh nilai konsentrasi PGPR yang rendah yaitu $10 \mathrm{ml}$ dan $5 \mathrm{ml}$. Hal ini ditunjukkan oleh penelitian Iswati (2012) yang menyatakan bahwa konsentrasi $12.5 \mathrm{ml}$ PGPR mempengaruhi kecepatan pertumbuhan tanaman tomat dan respon terhadap hormon biasanya tidak terlalu tergantung pada jumlah absolut hormon tersebut. Dewi (2008) menambah akan tetapi tergantung pada konsentrasi larutan yang digunakan dan hormon inilah yang mempengaruhi pertumbuhan tanaman meskipun konsentrasi larutan PGPR ditinggikan sampai batas tertentu, tapi perbedaannya tidak signifikan.

Tabel 5. Panjang petiol pepaya di lapangan pada 5 MST

\begin{tabular}{|c|c|c|}
\hline Peubah & Tinggi tanaman $(\mathrm{cm})$ & Panjang petiol $(\mathrm{cm})$ \\
\hline K1 & 14.1 & $3.32^{\mathrm{a}}$ \\
\hline $\mathrm{K} 2$ & 14.6 & $3.01^{\mathrm{b}}$ \\
\hline K3 & 13.9 & $3.02^{\mathrm{b}}$ \\
\hline Keter & $\begin{array}{l}: \text { Angka yang diikuti } \\
\text { kolom yang sama tid } \\
\text { Duncan taraf 5\% }\end{array}$ & $\begin{array}{l}\text { uruf yang sama pada } \\
\text { berbeda nyata pada uj }\end{array}$ \\
\hline
\end{tabular}

\section{Fase Generatif}

Konsentrasi, perendaman PGPR dan interaksi konsentrasi dengan perendaman PGPR tidak mempengaruhi waktu bunga pertama muncul, tinggi kedudukkan bunga, jumlah pohon betina, jumlah pohon hermaprodit, jumlah bunga betina dan jumlah bunga hermaprodit. Menurut Salisbury dan Ross (1995) tanaman akan menghasilkan bunga jika tanaman tersebut telah melewati masa vegetatif. Penelitian ini tidak sama dengan penelitian Taufik (2010) yang menyatakan bahwa aplikasi PGPR pada benih cabai mampu meningkatkan pertumbuhan generatif tanaman cabai.

\section{KESIMPULAN}

Konsentrasi PGPR dan lama perendaman tidak mempengaruhi kecepatan perkecambahan benih pepaya sukma dan tidak mempengaruhi pertumbuhan bibit sampai 4 MST, kecuali jumlah daun dan diameter batang. Diameter batang terbesar pepaya diperoleh pada bibit dengan perlakuan $15 \mathrm{ml} \mathrm{L}^{-1}$ air 60 menit, $15 \mathrm{ml} \mathrm{L}^{-1}$ air 60 menit dan $15 \mathrm{ml} \mathrm{L}^{-1}$ air 60 menit. Konsentrasi dan lama perendaman benih PGPR juga tidak mempengaruhi pertumbuhan awal pepaya hingga pembentukan bunga pertama kecuali konsentrasi
PGPR terhadap panjang petiol pada 5 MST. Petiol terpanjang diperolehi pada perlakuan $15 \mathrm{ml} \mathrm{L}^{-1}$ air PGPR.

\section{DAFTAR PUSTAKA}

Dewi, I.R. 2008. Peranan dan fungsi fitohormon bagi pertumbuhan tanaman [skripsi]. Bandung(ID): Univeritas Padjadjaran.

Dita, R.S. 2014. Pengaruh konsentrasi dan lama perendaman plant growth promoting rhizobacteria (PGPR) pada pertumbuhan tanaman seledri (Apium graveolens $\mathrm{L}$.) [skripsi]. Pekalongan(ID): Universitas Pekalongan.

Gardner, F.P., Pearce, R.B., Mitchell, R.L. 2008. Fisiologi Tanaman Budidaya. Susilo $\mathrm{H}$, Subiyanto, penerjemah. Jakarta (ID): UI Pr. Terjemahan dari: Physiology of Crop Plants.

Harjadi, S.S. 1979. Pengantar Agronomi. Jakarta (ID): PT Gramedia.

Iswati, R. 2012. Pengaruh dosis formula pgpr asal perakaran bambu terhadap pertumbuhan tanaman tomat (Solanum Lycopersicum syn). Di dalam: Jatt 1(1); 2012 April; Gorontolo, Indonesia. Gorontolo (ID): Fakultas Pertanian Universitas Negeri Gorontalo.

Maunuksela, L. 2004. Molecular and physiological characterization of rhizosphere bacteria and frankia in forest soils devoid of actinorhizal plants [disertasi]. Amsterdam (NED): Biocentri Wikki Universitatis Helsingiensis.

[PKHT] Pusat Kajian Hortikultura Tropika Institut Pertanian Bogor. 2013. Pemetaan Sentra Produksi Buah. Produksi buah [Internet]. [diunduh 2014 Mar 17]. Tersedia pada: Tersedia pada: http//www.PKHT.or.id/sentra produksi buah

[PKP] Pusdatin Kementerian Pertanian. (2013). Statistik Makro Sektor Pertanian Volume 5 No.1 Tahun 2013. Jakarta(ID).

Salisbury, F.B., Ross, C.W. 1995. Fisiologi Tanaman Jilid 1. Diah, R.L., Sumaryono, penerjemah. Bandung (ID): ITB Pr. Terjemah dari: Plant Physiology. 
Sujiprihati, S., Suketi, K. 2009. Budidaya Pepaya Unggul. Jakarta(ID): Penebar Swadaya.

Suketi, K., Imanda, N. 2011. Pengaruh jenis media tanam terhadap pertumbuhan bibit pepaya (Carica papaya L). Di dalam: Kemandirian Produk Hortikultura untuk Memenuhi Pasar Domestik dan Ekspor dan Seminar Nasional Perhimpunan Hortikultura Indonesia; 2011 Nov 23-24; Lembang, Indonesia. Bogor (ID): Departemen Agronomi dan Hortikultura. hlm 777-790. Tersedia pada: http://iirc.ipb.ac.id/jspui/bitstream/123456 789/43189/2/20seminar\%20[PERHORT I.ppt] [diunduh 2014 Nov 17].
Suketi, K., Yunianti, R., Chairunnissa, V.O. 2011. Pengujian pertumbuhan beberapa bibit papaya hibrida (Carica papaya L). Di dalam: Kemandirian Produk Hortikultura untuk Memenuhi Pasar Domestik dan Ekspor dan Seminar Nasional Perhimpunan Hortikultura Indonesia; 2011 Nov 23-24; Lembang, Indonesia. Bogor (ID): Departemen Agronomi dan Hortikultura. hlm 1065-1075. Tersedia pada:http://iirc.ipb.ac.id/jspui/bitstream/1 23456789/43189/2/20seminar\%20[PERH ORTI.ppt] [diunduh 2014 Nov 17].

Taufik, M. 2010. Pertumbuhan dan produksi tanaman cabai yang diaplikasi plant growth promoting rhizobacteria. Di dalam: J. Agrivigor 10(1): 2010 September-Desember; Kendari, Indonesia. Kendari(ID): Fakultas Pertanian Universitas Haluoleo. hlm 99107.

Utami, R.D., Widodo, W.D., Suketi, K. 2013. Respon pertumbuhan bibit pepaya pada delapan jenis komposisi media tanam. Di dalam: Kartika JG, Suwarno WB, Ardhie SW, Sanura CPE, Fitriana FN, editor. Membangun Sistem Baru Agribisnis Hortikultura Indonesia pada Era Pasar Global; 2013 Okt 9; Bogor, Indonesia. Bogor (ID): Perhimpunan Hortikultura Indonesia (PERHORTI). hlm 80-88; Tersedia pada: http://www.unud.ac.id/ ind/wp-content/uploads/seminar-nasionalper horti_new.pdf [diunduh 2014 Nov 16]. 